\title{
THE UNIVERSITY LIBRARY AND THE STATE
}

\author{
BY ROGER H. McDONOUGH
}

Roger H. MCDonough, who has degrees from Rutgers and Columbia, is now State Librarian of New Jersey. After serving as Reference Librarian of the Rutgers Library, he became City Librarian of New Brunswick before going to Trenton. During the war he was assigned to the Historical Section of the Army Air Force. He is a member of the Council of the American Library Association and Chairman of the Committee on Federal Relations. He has also acted as a consultant to the U.S. Office of Education.

\section{I}

AM GRATEFUL for the opportunity to join with you this evening in these pre-dedication ceremonies and to speak briefly on the subject of the Rutgers University Library's role in relation to other reference and research libraries in New Jersey. I propose to attempt to relate Rutgers to the total library complex, to examine some of the exchange services and to suggest a few lines of inquiry into possible future developments and what these may entail in terms of staff and other resources. I speak as one who is concerned with the total library services available to the citizens of our state and who views the Rutgers Library system as a key element in the new library structure we are attempting to develop in New Jersey.

I think it wise to begin with a brief account of the library facilities now available to our citizens. At the local level, we now have in New Jersey 258 free public libraries, including twelve county libraries serving the less urban areas. In addition, we have about 600 school libraries serving almost all of our secondary and many of the elementary schools. In the field of business and industry, New Jersey presents an outstanding concentration of more than one hundred "special" libraries. At the college and university level, there are, in addition to Rutgers and Princeton, six teachers college libraries and 30 other college libraries. The State Library in Trenton plays a unique role in the total library picture in that it supplements the collections of other libraries-principally the public and school libraries-by lending books directly from its own extensive collections and by borrowing books from other libraries to re-lend. 
In the past few years, several important developments have strengthened the library situation in our state. A $195 \mathrm{I} \mathrm{report}^{1}$ of a survey of the need for better library training facilities resulted in the creation, in 1953, of the Rutgers Graduate School of Library Service. Under brilliant leadership, this school is now turning out significant numbers of qualified librarians for service in New Jersey libraries. In February, I 956, a legislative study commission report ${ }^{2}$ was published which crystallized the findings of several years of research into the condition of our public libraries. This report revealed that more than half the people in the state have no public library service or only sub-standard service and that the majority of our public library units are too small to render adequate service. To remedy this situation, the Commission recommended, among other things, a $\$ 2,000,000$ state aid program, which, when matched by an additional $\$ 2,000,000$ in local funds, would bring our public libraries up to an adequate minimum level.

It is encouraging to be able to report that there appears to be growing sentiment for the adoption of this state aid program. The passage of a modest Federal Aid to Libraries Bill this past June may well provide the spark to get the state aid program under way.

In the school library field, we have had in the past generation or so what amounts to a revolution. Not too long ago, the secondary school library either did not exist or it was something of a stepchild. In 1956 , it is a rarity to find a secondary school without a library, and an increasing number of school districts are providing elementary school library facilities.

This library reform movement has, I believe, immediate and direct implications for the Rutgers Library. The improvement in our public and school libraries means that the flood of students entering Rutgers in future years will be more skilled library users and thus will be better prepared to utilize the resources of the University library than did their predecessors. Concomitantly, we may expect that the undergraduate body will make greater demands upon the library than ever before.

1 The Professional Education and Training of Library Personnel in New Jersey, a report to the Commissioner of Education. Trenton, March I6, I95 I.

2 Commission to Study Library Services in New Jersey, Better Libraries for New Jersey, Final report of findings and recommendations. Trenton, January, 1 956. 
We have less detailed, critical knowledge of our special libraries than we do of the public and school libraries. It is reasonable to assume, however, that, since the libraries of industry and business were created in response to specific needs, they will continue to receive adequate support from their respective sponsors. However, there is need for investigation to determine whether these special libraries are being exploited fully through cooperative interlibrary methods.

We are less certain that all is well in our college and university libraries, and this particular field represents an important piece of unfinished business for the library planners. Some beginning work was done a few years ago by a sub-committee of the Library Development Committee of the New Jersey Library Association, but, when the Committee decided to concentrate first upon local public libraries, the study was suspended for the time being. Only recently the Division of Higher Education in Trenton instituted a study of the resources of the teachers college libraries to determine whether they are in a position to meet the challenge of increased enrollments. Three of the six colleges have just completed library building programs and it is apparent that the present concern is with the internal resources that are available to students and faculty. In New York, the State Board of Regents is conducting a survey of needs of all college and university libraries. The emphasis in the first report of this survey ${ }^{3}$ is upon cooperative and integrated services, and for this reason I believe we should follow its progress closely.

To turn now to the Rutgers University Library itself, the dominant fact that confronts us is that Rutgers, in recent years, has become a university of tremendous size and scope, and the library has undergone a corresponding "sea change" that few of us yet comprehend fully. This wonderful new building, for example, is only the "main library" for a large system which includes branches in Newark and Camden and outstanding subject collections in such fields as law and pharmacy in Newark, and agriculture and microbiology in New Brunswick, to name only a few. The integration of these various elements into a unified library system is a herculean task that undoubtedly will continue to tax the energies of the librarian and staff for years to come. The creation of new graduate schools and the

\footnotetext{
${ }^{8}$ New York Regents' Committee on Integration of College and University Library Resources in New York State, A Plan for Meeting College Library Problems, I 954.
} 
enlarged graduate study program in the older disciplines add further to the problems which the library is striving to solve. That the library is advancing toward its goal of becoming an outstanding research facility is indicated by its admission this year into the Association of Research Libraries, an organization which is limited in number to the 50 largest research libraries in the country. To be accepted into this select company is a signal honor, for, in addition to its concern with the quantitative aspects of collections and book budgets, the more basic ARL tests are qualitative and involve the breadth and depth of the research programs. It should be noted that the Rutgers Library was admitted only because another institution had been dropped for failure to maintain standards, a circumstance that carries its own moral.

At the same time that the Rutgers Library has extended its services to faculty and students, it has continued its traditionally generous loan policy to libraries and individuals outside the university. At the present time, Rutgers is lending to more than 2,000 individual borrowers, most of whom live in the New Brunswick area. In addition, an extensive interlibrary loan business, much of which is devoted to the exchange of thesis materials, is carried on with other colleges and universities outside the state. In this instance, Rutgers is a "debtor," inasmuch as it gets the better of this exchange arrangement. On the other hand, Rutgers is distinctly a "creditor" vis-â-vis the special libraries of the state, more than 60 of which borrow widely from the University. One of these user firms was grateful enough for the services it received to present a group of scientific periodicals to Rutgers estimated to be worth $\$ 20,000$. These volumes may not be prime research materials for the industry concerned, but they make excellent teaching materials within the University. Perhaps this is a field in which the "Friends of the Rutgers Library" can be of assistance in encouraging similar donations.

I applaud the generous loan policies under which Rutgers has operated and I would like, if possible, to see them extended beyond their present scope. There are problems involved in lending materials off-campus, of course, and I think we should recognize them. At times, for example, faculty members have protested vigorously when certain books and periodicals have been lent to other libraries. In addition, interloan requests consume valuable staff time, and for 
this reason, Rutgers and the State Library, by mutual agreement, recently abandoned the arrangement whereby the State Library borrowed books from Rutgers in some numbers for reloan to other libraries.

Obviously, the needs of faculty and students must have first priority at all times. A university library, however, is a tremendously valuable (and costly) resource that must be exploited as fully as possible. If the requests that are made upon Rutgers are legitimate ones and Rutgers, for lack of staff, is unable to give as good service as it would like, then the University and the State budget authorities should be asked to provide the additional assistance needed. The interlibrary loan process is not an inexpensive one, but it is the most effective and economical technique we have found to make scarce items available over a wide area.

Another line of attack in meeting interlibrary loan requests that should be thoroughly explored is the more extensive use of photoduplication services. Frequently, all that a borrower wants or needs is a chapter or section from a book, periodical or government document. In those instances in which no copyright problem is involved, a quick photo-copying of a few pages will provide exactly the material needed. Again, this process is not inexpensive but, compared with purchasing, storing and making available duplicate copies of the publication itself in other areas of the State, the cost is small indeed.

I believe that the time is most opportune for the Rutgers library to do some stock taking and course-setting. The Library's new status as part of a full-fledged state university and the flood tide of students promised us within a few years lend special importance to the necessity of planning wisely for the library's future growth. Such planning must embrace the most careful consideration of the manner in which available space is to be used. The collections of university libraries have an alarming habit of doubling in size every sixteen years, ${ }^{4}$ a rate that requires even the largest institutions to seek permanent solutions to the problem of mass accumulation. Dr. Keyes Metcalf, former Librarian at Harvard and now a member of the Rutgers Library School faculty, has been one of the leaders in the movement

${ }^{4}$ Dix, William S.-Financial Problems of University Libraries: A Summary (Prepared for the Association of American Universities). Princeton University, March, I 954 , p. 22. 
for a regional storage facility to which colleges in the Northeast could send little used materials for storage. This concept is similar in some respects to that of the Midwest Interlibrary Center in Chicago which services some I 5 universities in that area. Fortunately, New Jersey has the statutory authority to erect a central storage facility, and there is hope that such a building will be erected as part of the State Library within a few years.

Meanwhile, all scholarly libraries, including Rutgers, must make every cooperative effort to delineate areas of responsibility so that they will not compete with one another unnecessarily. A modest beginning has been made, for example, in collecting and microfilming New Jersey newspapers and I think we should pursue this line of activity much further. It is not easy for a university library to delimit itself, however, particularly when the university is a growing one and deans and faculty members are intent on building up collections in their respective specialties. Nevertheless, if the library's holdings are to be kept within controllable limits, continuing pragmatic tests must be made of all collections.

In closing, I want to say explicitly what has been implicit in the remarks of all of us this evening. It is simply this: that magnificent as this new building is, it is not an end but a beginning. Now the library must turn its attention to utilizing this wonderful new resource to its ultimate capacity. In so doing, it must prepare for a much larger-and more sophisticated-group of library users at the undergraduate level as well as a constantly expanding research program at graduate level. Exactly what this will mean in terms of staff and other resources I am unable to predict. It is logical to assume that the library will need to develop strong collections in a great many diverse fields and I would guess that there would be need for competent subject specialists on the staff to carry out this task. Beyond this, I would hope that Rutgers would continue to be generous in meeting requests for the rare, out-of-print, or otherwise scarce items that libraries of lesser size may need. All this implies a solid financial backing.

Happily, there are encouraging signs that the value of good library service is receiving increasing recognition by our Legislature, the Governor, and the people of the State. The events of the past few years-including the completion of this and other State-financed 
library buildings; the creation of the Graduate Library School; the passage of progressive library legislation, including a new certification law; and the increased support provided for the State Library -all indicate, to my satisfaction, at least, that the library climate is becoming increasingly better in New Jersey. I am convinced that this situation augurs well for the future of Rutgers University Library.

Finally, may I take this opportunity to express the deep personal satisfaction I feel at the completion of this library building. As a former student assistant and staff member who enjoyed many happy years in the Voorhees Library under that splendid gentleman and fine librarian, George A. Osborn, I have always held the Rutgers Library in the deepest affection and respect. I have been privileged to share some of Mr. Cameron's thinking in connection with the planning of this building and I take this occasion to salute him for a truly magnificent accomplishment. He may indicate that other people helped, and many did, but all of us know that, in the last analysis, this heap of bricks and stone and steel and mortar, and the shape in which it is cast, is the direct result of his guiding genius and inspiration. I am sure that he and the staff, the faculty and students, and our loyal alumni and "Friends of the Library" will enjoy and rejoice in it for many years to come. 